\title{
The Trial: a bureaucratic system in Zizek's view
}

\author{
Ismaeil jangizahy ${ }^{1,}$, , Shahram Afrougheh ${ }^{2}$ \\ ${ }^{1}$ M.A. English Literature, Islamic Azad University, Boroujerd Branch, Iran \\ ${ }^{2}$ Assistant Professor of English Literature Islamic Azad University, Boroujerd Branch, Iran
}

\section{Email address:}

ijangizahy@yahoo.com (I. Jangizahy),shahram_afrougheh@yahoo.com (S. Afrougheh)

\section{To cite this article:}

Ismaeil jangizahy, Shahram Afrougheh. The Trial: A Bureaucratic System in Zizek's View. International Journal of Literature and Arts. Vol. 1, No. 3, 2013, pp. 59-62. doi: 10.11648/j.ijla.20130103.17

\begin{abstract}
In this paper we engage with the bureaucratic project from Zizek's view in The Trial by Kafka. Kafka has given an exaggerated, fantastic and subjectively distorted expression to modern bureaucracy and the fate of the individual within it. The first discourse is bureaucracy expressed through post-bureaucratic discourses which very much define the main stream of management thought today, highlighting the need for organizational openness which can only come through liberation of management from the closed structures of the bureaucracy. The second discourse of Zizek's view defends the bureaucratic ethos of liberal-democratic institutions. We point to the limitations of both discourse of the dominance of bureaucracy by discussing key aspects of Slavoj Žižek's work. Žižek displaces the state socialism, and the dominance of bureaucracy is quite obvious. State bureaucracies administer all possible aspects of life. In each case bureaucratic designate are in positions of state power. The bureaucracy system is always watching, always gathering information, and contributes to broader efforts to reimagine democracy.
\end{abstract}

Keywords: Bureaucracy, Social institution, Liberal-democratic, Post-bureaucratic

\section{Introduction}

Bureaucracy, to Kafka, is a way for people to avoid personal responsibility. Joseph $\mathrm{K}$. in The Trial is tormented by this stranger, nameless bureaucracy. In neither case is the "enemy" revealed, nor even the source or cause of the bureaucracy's antagonism toward the main character. It simply is. Kafka's characters, and his readers, are confronted with the terror of absolute helplessness. In the face of the machine, what chance does the individual have? In Kafka's modernist allegories, the main character confronts

These realities directly, but Kafka is expressing a typical modernist concern: that the modernization of commerce dehumanizes the people involved with it. Once the system takes precedence over the individual, the individual loses his autonomy. This loss of autonomy is important in the anxiety that permeates Kafka's work. One cannot live outside of the system, nor can one exist in opposition to it. There is complicity, plain and simple, and one must live at the mercy of even the lowest agents of the system. Although the concept of bureaucracy has entered into the sphere of the social sciences and the public domain and now enjoys widespread currency, it remains so imprecise that we can justly continue to question the identity of the phenomenon to which it claims to refer. To ask 'What is bureaucracy?' is not simply to question the dimensions, the character, the origin or the future of a social phenomenon; it is also, implicitly or explicitly, to raise the fundamental question concerning the mode of being of this phenomenon. The bureaucratic basic is a kind of rational-law structure that this system foundation is legitimate and it is a bridge between government and society:

Bureaucracy confronts us as a phenomenon of which everyone speaks and believes to have experienced in some way, and yet this phenomenon strangely resists conceptualization. (Lefort 89)

Bureaucracy is a concept in sociology and political science referring to the way that the administrative execution and enforcement of legal rules is socially organized. This office organization is characterized by standardized method, formal division of responsibility, hierarchy, and impersonal social relationships. According to organizational design theory, a major benefit promised by the bureaucratic form is that the top executive would have control over the entire organization, and the outside world would know who hold responsible Generally: "we all know very well that bureaucracy is not all-powerful, but our 'effective' conduct in the presence of bureaucratic machinery is already regulated by a belief in its almightiness" (Žižek 2009: 34). 
In The Trial, Kafka has a diverse set of characters present themselves are preventatives of the Law: a priest in the Cathedral who calls himself the prison chaplain, the Advocate in his home attached to a courthouse, the Inspector in K.'s home, the Examining Magistrate in the courthouse, the official painter in his studio, lackeys in the bank at which $\mathrm{K}$. works, and the unnamed men, apparently without office, who execute $K$. in the name of the state on a riverbank. A variety of women also primarily concern $\mathrm{K}$. exclusively in their sexual connection, but its presence is nowhere more obvious than in his $\mathrm{n}$ to state officials and their possible ability to help persuade the officials with their charms.

Most of Kafka's stories theme is about bureaucracy democracy novel, The Trial. That skepticism toward democracy is not a recent radical gesture but a central element in Zizek's thinking is also clear in the fact that one of his most fundamental theoretical insights concerns the constitutive non-universalizability of liberal democracy. Thus, in The Sublime Object of Ideology, written before the collapse of communism, Zizek refers to the universal notion of democracy as a "necessary fiction." Adopting Hegel's insight that the Universal "can realize itself only in impure, deformed, corrupted forms," (Zizek 148). He emphasizes the impossibility of grasping the Universal as an intact purity. In all his work thereafter, Zizek struggles with the relation between democracy and universality; concerned with the way that contemporary adherence to democracy prevents the universalizing move proper to politics.

Then, The Trial, the title has two levels of meaning, referring literally to some ominous legal action to which the protagonist, Joseph K., its told he will soon be subjected, and figuratively to the trial of chronic anxiety he is forced to endure while he awaits his trial an anxiety that begins the instant he learns that he is accused of some unspecified crime, a crime that is terrifying precisely to the extent then, it is left undefined. Joseph $\mathrm{K}$. is the modern man, who is basically anonymous and remote in his affect. He is certainly reasonable but does not understand the nature of the bureaucratic machinery in which he has become enmeshed.

The man gave his permission with a wave of the hand. 'You see, this gentleman is the information clerk. He gives defendants who are waiting all the information they need, and since our court is not very well known among the public, there are many enquiries. He knows the answer to all the questions; you can test him out some time if you feel like it. (The Trial 55)

Josef K.'s entry into the dream-like story coincides with his entry into the legal sphere, when he is arrested one morning for no apparent reason. The court that prosecutes him does not have a determinate place, nor is it everywhere in general. It is always nearby for example, it operates in the room of his neighbor, Fräulein Bürstner, where a nightstand is used as a makeshift desk for the hearing; on the fifth floor of a poor suburban tenement house, where the first inquiry takes place; and behind the door of a junk room in K.'s workplace, where the two guards from the morning arrest are being flogged after $\mathrm{K}$. reported them to the examining magistrate.

$\mathrm{K}$. is quick to learn that the court's presence consists of a dumb network of representatives and affiliates who perpetuate its functioning. Among these delegates and substitutes are the examining magistrate, the prison chaplain, and the chain of doorkeepers within The Trial's parable. As K. becomes absorbed into the court organization, he also needs intermediaries with whom to interact.

\begin{abstract}
'It's better if you hand over your things to us now, rather than in the depot,' they said, 'things are often misappropriated in the depot and, anyway, they sell everything off after a certain time, whether the case in question has been concluded or not. And the time these trials take, especially recently! (The Trial 6)
\end{abstract}

Above quote paragraph it could well represent a tyrannical conscience or superego, of course; but it is also an image of the dehumanizing atmosphere created by the moral irresponsibility of bureaucracies. Therefore, Kafka has given an exaggerated, fantastic and subjectively distorted expression to modern bureaucracy and the fate of the individual within it. It is very exaggeration which articulates the fantasy regulating the libidinal functioning of the effective and real bureaucracy. The so-called Kafka's universe is not a fantasy-image of social reality but, in contrast, the setting of the fantasy which is at work in the midst of social reality. We all know very well that bureaucracy is not powerful, but our effective conduct in the presence of bureaucratic machinery is already regulated by a belief in its almightiness.

\section{The First Discourse in The Trial}

The first discourse is bureaucracy. Zizek's theorization of democracy relies on a conceptual insight into the impossibility of a pure form. A pure form will always be "stained" or in some way in pure. The symbolic order, say, or a given ideological field, will have within it non-rational kernels of intensity, objects of attachment, excesses of enjoyment. Formal arrangements like the moral law and the democratic invention can't escape this excess; indeed, they produce and rely on it. It is an efficient tool in the hands of someone that knows how to control it. The subsequent writers, impressed by the increasing bureaucratization of modern society and by the rise of totalitarian regimes in the East and the West, had often seen bureaucracy as an oligarchic system of political domination. Bureaucracies after all can be used to enforce environmental protection and provide welfare payments to the poor as well as to run wars and spy operations:

This is state bureaucracy at its most crazy. Are we aware that this is our only true contact with the divine in our secular times? What can be more "divine" than the traumatic encounter with the bureaucracy at its craziest when, say, a bureaucrat tells me that, legally, I don't exist? It is in such encounters that we get a 
glimpse of another order beyond mere earthly everyday reality. Like God, bureaucracy is simultaneously all powerful and impenetrable, capricious, omnipresent and invisible. (Žižek 2006: 116).

The extended bureaucracy represented in The Trial and the corruptness of all those associated with the courts is an obvious representation. In the courtroom, K. makes the connection evident, acknowledging the secrecy and corruption on which the discourse is based. The Trial satirically calls attention to the multiplicity of the empire's courts which, in the novel, function far away from the place in the tenement hallways and attics where a never- ending series of judges work in the cramped, often dark and stuffy, spaces.

In practice, state bureaucracies in capitalist societies are strongly influenced by corporate elites via provision of jobs, perks and most basically by providing a reason for the state bureaucracies to exist. The expansion of modern bureaucracies occurred in conjunction with the rise of modern states and the professional military in the service state. This system was based on considerable local economic and political self-reliance. There were many local centers of power, including the church, estates, local aristocrats and provincial centers. People had close ties and identified psychologically with family, land, manor and church. All these aspects were resistant to the extensive division of labour and centralised control required for the operation of bureaucracy.

Žižek's believes that under state socialism the dominance of bureaucracy is quite obvious. State bureaucracies administer all aspects of life. In each case bureaucratic designate are in positions of state power. The bureaucracy system is always watching, always gathering information, and always knowing. "The whole mystique of bureaucracy at its most sublime hinges on this gap: you know the facts, but you can never be quite sure of how these facts we will be registered by bureaucracy" (Žižek 2008: 23).

This principle has the greatest connection to those inside bureaucracy. One approach to social change is the long march through institutions. This means climbing the existing hierarchical ladders to obtain formal positions of power, where supposedly one can then have some impact on social directions. Kafka's bureaucracy belongs indubitably to the inner, unwritten law; it epitomizes the crazy reverse of the society that we encounter precisely when we escape unawareness, external legal regulation. It functions as a strange body within us, what is in us more than ourselves, an obscene ex-tirade agency which demands the impossible and mockingly observes our helpless attempts to follow with it. The uncanny excess that disorders the simple opposition between external social law and unwritten inner law, between desire and law-- that is to say, a point at which desire itself becomes law, a point at which insistence upon one's desire compares to fulfilling one's duty, a point at which duty itself marked by a stain of (surplus) enjoyment, And it is these short circuits which enable us to locate the paradox of the Kafka's post-bureaucratic machinery, far from being reducible to the external social law; it epitomizes the per- verse reverse of the inner unwritten law itself. So, the democratic invention is extraordinary; yet, it is also rooted in a fundamental impossibility a pure form. When theorizing democracy, then, one is confronted by the question of the proper relation to this impossibility of a pure form. Should one view it as the strength of democracy and thereby assume this impossibility, this inevitable failure and barrier? Should one specify and contextualize it, seeking thereby to understand how it might function in a given historic period or what its relationship is to a given mode of production?

Zizek takes the second position. To explain why this answer is compelling, I now consider his analysis of the democratic stain more closely. Zizek develops his account of the formal stain through an exploration of the structural homology between Kant's categorical imperative, the Jacobin's democratic terror, and the psychoanalytic account of castration. Therefore, democracy requires that the place of power remain empty; the Jacobins sought to ensure this emptiness, recognizing that any attempt to occupy the empty place is by definition usurpation.

\section{The Second Discourse in The Trial}

The second discourse in The Trial of Zizek'view defends the bureaucratic ethos of liberal-democratic institutions. The bureaucratic mind is sustained by the self-perpetuating mechanics of government and the claptrap of its own rhetoric. Marxist critics, in all their exotic colorations, have always taken, and will naturally continue to take, great care to avoid such an uncomfortable truth, for Marxists of all sorts (like the social insects generally) possess the bureaucratic mind and need political structure to provide them with security and self-definition. If Marxism is a substitute for religion, bureaucracy is its theology. Obviously Kafka's woeful parables are not about Marxism, as such; if they were, his work would be no more than the narrowest sort of propaganda and it would be hard to explain its continuing relevance today among readers of various ideological faiths. The object of his chronic dismay is something far more prevalent and insidious: at the heart of his obsessive and horrifying narratives is an unfathomable bureaucracy, one that has emerged through a combination of inertia, default, and the institution of political power, perpetuating itself by feeding upon the rights of the people it was ostensibly designed to serve.

Žižek's position can be made clear by examining how he reads a curious remark which Kafka passed in a private correspondence, in which he is claimed of bureaucracy that the notoriously primary form of social organization in the universe of his novels that it was closer to original human nature than any other social institution. Žižek's view of Kafka stands against what he calls the modernist reading of his novels as examinations of the modem world characterized by the absence of God. Žižek argues that this modernist reading misses what is vital in Kafka. Kafka's problem is that in this universe God is too present: 
The power and acuity of his legal mind were admirable, but in that respect many of the others were at least his equal; none, however, could match the fierceness with which he defended his opinions. K. had the feeling that even if he could not convince an opponent, Haster at least put the fear of God into him; many drew back merely at the sight of his outstretched forefinger. (The Trial 174)

Kafka's universe is a world in which God who up to now had held himself at an assured distance has gotten too close to us. From this modernist perspective, the secret of Kafka would be that in the heart of the bureaucratic machinery, there is only emptiness, nothing: bureaucracy would be a mad machine that works by itself.

This could well represent a tyrannical conscience but it is also an image of the dehumanizing atmosphere created by the moral irresponsibility of bureaucracies. Josef K. like other Kafka's heroes embodies the type produced by modern institution of work, government, and commerce. In The Trial the court and its paradoxes may be seen as the description of a corrupt bureaucratic system. Kafka's model of the self is being transformed into the bureaucratic man so that he is unable to decision as an autonomous person. $\mathrm{K}$. is entirely devoted to his work and is detached from his family (he fails to visit his mother). Also in his portrayal of bureaucracy Kafka shows another feature of modern societies, the invisibility of their rules.

Eventually, Joseph K. is killed, ending the trial of his existence before that other ghostly trial for an unnamed crime can take place assuming that it ever would. Like most of Kafka's narratives, this novel is dotted with strangely comic episodes; but the comedy does not provide release from the oppressive atmosphere of an irrational but omnipotent bureaucracy. This is a far different realm from that reflected in Kafka's black and white parables, where instead of buoyancy, there is only the heavy slogging of nightmarish struggle; and instead of joy, there is only the chugging of political machinery, mindlessly controlling everything signifying a bureaucracy that has severed all connection with human need.
In The Trial of Kafka, it is usually said that in the irrational universe of this novels, Kafka has given an exaggerated, fantastic and subjectively distorted expression to modern bureaucracy and the fate of the individual within it. In saying this we overlook the crucial fact that it is this very exaggeration which articulates the fantasy regulating the libidinal functioning of the effective and real bureaucracy itself. The so-called Kafka's universe is not a fantasy-image of social reality but, on the contrary, the setting of the fantasy which is at work in the midst of social reality itself. We all know very well that bureaucracy is not all-powerful, but our effective conduct in the presence of bureaucratic machinery is already regulated by a belief in its almightiness

\section{Conclusion}

Therefore, Kafka's works reveal his interest in the complex interrelationships of constitutional, civil, administrative, and criminal law. The law is made by a bureaucratic society and tool for it to obligate its members to accept it and follow its orders. As Kafka shows, success within an institution requires one to accept its rules, including its system of hierarchy, so that anything different becomes intolerable, even unthinkable. In modern bureaucratic society, the heroes of Kafka's novels are clear with unusual events that change their behavior and mind.

\section{References}

[1] Lefort, Claude. The Political Forms of Modern Society Bureaucracy, Democracy, Totalitarians. Ed. John B. Thompson. Cambridge, Massachusetts, 1986.

[2] Kafka, Franz. The Trial. Trans. Mike Mitchell. United State: Oxford university press, 2009.

[3] Žižek, Slavoj. The Parallax View. Cambridge: MIT Press, 2006.

[4] Violence. New York: Picador, 2008.

[5] The Sublime Object of Ideology. London: Verso, 2009. 